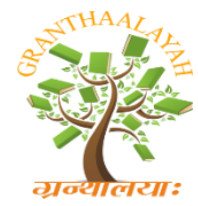

$$
\begin{gathered}
\text { INTERNATIONAL JOURNAL OF RESEARCH - } \\
\text { GRANTHAALAYAH } \\
\text { A knowledge Repository }
\end{gathered}
$$

Science

\title{
FIBROUS SILICA-HYDROXYAPATITE COMPOSITE BY ELECTROSPINNING
}

\author{
Jesús Alberto Garibay-Alvarado ${ }^{1}$, León Francisco Espinosa-Cristóbal ${ }^{2}$, Simón Yobanny \\ Reyes-López ${ }^{* 3}$ \\ 1, 2, *3 Instituto de Ciencias Biomédicas, Universidad Autónoma de Ciudad Juárez, Envolvente del \\ PRONAF y Estocolmo s/n, C.P. 32300, Ciudad Juárez, Chihuahua, México
}

DOI: https://doi.org/10.29121/granthaalayah.v5.i2.2017.1701

\begin{abstract}
New nanocomposite membrane was fabricated by electrospinning. The nanocomposite combines a glass and hydroxyapatite (HA). This research proposed the incorporation of glass to counteract the brittleness of HA in a composite formed by coaxial fibers which will be used for bone replacement. Calcium phosphate ceramics are used widely for dental and orthopedic reasons, because they can join tightly through chemical bonds and promote bone regeneration. Precursors $\mathrm{HA}$ and $\mathrm{SiO} 2$ were synthetized through the sol-gel method and then incorporated into a polymeric PVP matrix; later they were processed by coaxial electrospinning to obtain fibers with an average diameter of $538 \mathrm{~nm}$ which were characterized with techniques such as Attenuated Total Reflectance-Fourier Transform Infrared Spectroscopy, Differential Thermal Analysis and Scanning Electron Microscopy. Chemical and physical characterization of the membranes evidenced fibers in a coaxial disposition with a glass core and hydroxyapatite cover. The microporous fibers have many potential uses in the repair and treatment of bone defects, drug delivery and tissue engineering. Through ATR-FTIR and SEM-EDX analysis the presence of characteristic chemical groups, the fiber composition and microstructure were determined.
\end{abstract}

Keywords: Nanofibers; Electrospinning; Hydroxyapatite; Nanocomposite; Glass.

CITE THIS ARTICLE: Jesús Alberto Garibay-Alvarado, León Francisco Espinosa-Cristóbal, and Simón Yobanny Reyes-López. (2017). "FIBROUS SILICA-HYDROXYAPATITE COMPOSITE BY ELECTROSPINNING.” International Journal of Research - Granthaalayah, 5(2), 39-47. https://doi.org/10.29121/granthaalayah.v5.i2.2017.1701.

\section{Introduction}

Until very recently the repair of the skeletal system was performed with the use of bone grafts, however, the difficulty of obtaining such materials from natural sources and donors allowed the introduction of non-biological materials which can be easily obtained through synthetic processes while they are also less likely to produce antigenic reactions (Dinarvand et al., 2011; 
Roveri et al., 2003). Significant efforts have been made to the field of biomaterials and bone tissue engineering. Glasses and ceramics can be bioactive they have the capacity to form an interphase with living tissue through physical and chemical interaction (Hench and Kokubo, 1998). Bioactive ceramics are used primarily for the reconstruction or substitution of parts of the skeletal system (Boccaccini, 2005). Calcium phosphate ceramics and silica bio glasses are used widely for dental and orthopedic reasons, due to their bioactive properties, while promoting bone regeneration in the area (Leeuwenburgh et al., 2008).

Hydroxyapatite $(\mathrm{Ca} 10(\mathrm{PO} 4) 6(\mathrm{OH}) 2)$ is the primary mineral component of human bones and teeth, it is a bioceramic, and can be obtained through a variety of chemical reactions such as hydrolysis or sol-gel method. Although this compound has been researched for the replacement of hard tissue, there are several characteristics that restrict its use in biomedical applications: absence of antimicrobial properties, brittleness and limited contact with the host tissue (Basu and Balani, 2011). The incorporation of silver to the material can promote antimicrobial activity (Reyes-López et al., 2015; López-Esparza et al., 2016), and, while brittleness is one of the major issues with the use of hydroxyapatite for load bearing applications, the introduction of glass can counteract this property and allow the manufacturing of a composite with bioactive capabilities which can withstand the physiological environment of the body. The use of silicate as a reinforcement component in flexible membranes has been researched with success improving the mechanical characteristics of such materials (Tian et al., 2015).

Electrospinning has received much attention as a method to fabricate submicron fibrous scaffolds for bone tissue engineering. Electrospinning, a simple and versatile technique, is capable of spinning fibers with diameters down to tens of nanometers (Reyes-López et al., 2015; RoqueRuiz et al., 2016). Long, thin, solid fibers can be generated as the electrified jet (viscous solution) is continuously stretched by electrostatic forces (Zhao et al., 2008). Electro spun submicron fibers mimic the features of native extracellular matrix (ECM) and provide a niche for cell arrangement (Zafar et al., 2016).

Through the electrospinning technique membranes of nanofibers of different compositions can be produced, to be used as scaffolds for tissue reconstruction purposes. There is no doubt that the electrospinning has gained popularity in recent years for bio-dental applications mainly for tissue engineering scaffolds. The progress of tissue engineering is promising for the regeneration of oral and dental tissues. Various polymer and ceramic composite materials have been electro spun to fabricate scaffolds for regeneration of dental tissues (Zafar et al., 2016). The objective of this contribution was to prepare core/shell fibers composed of silica glass and hydroxyapatite. The fibers were analyzed regarding their morphology, chemical composition, thermal properties and crystalline phases.

\section{MATERIALS AND METHODS}

\subsection{Materials}

Calcium nitrate tetrahydrate $(\mathrm{Ca}(\mathrm{NO} 3) 2.4 \mathrm{H} 2 \mathrm{O})$, triethyl phosphite $((\mathrm{C} 2 \mathrm{H} 5 \mathrm{O}) 3 \mathrm{P})$, ethanol, $\mathrm{HCl}$, tetraethyl orthosilicate (TEOS) and poly (vinyl pyrrolidone)(PVP) with average molecular 
weight of 360,000 were used as raw materials for preparing the sol, all reagents were purchased from Sigma-Aldrich Co.

\subsection{Synthesis of Silica Sol}

The silica sol-gel was prepared dissolving tetraorthosilicate in ethanol-water solution; the molar proportions for tetraorthosilicate, ethanol, deionized water and concentrated $\mathrm{HCl}$ were 1:2:2:0.1. First the TEOS was dissolved in ethanol, followed by the mixing of water and $\mathrm{HCl}$ used as catalyst under constant stirring for $30 \mathrm{~min}$ at room temperature.

\subsection{Synthesis of Calcium Phosphate Sol}

This synthesis was carried out using the method described by Lee and Kim in 2014. The $(\mathrm{Ca}(\mathrm{NO} 3) 2.4 \mathrm{H} 2 \mathrm{O})$ was dissolved in ethanol and the $(\mathrm{C} 2 \mathrm{H} 5 \mathrm{O}) 3 \mathrm{P}$ was hydrolyzed in ethanol. The calcium nitrate solution was added by dripping to the triethyl phosphite during $1 \mathrm{~h}$. The solution was stirred vigorously for $24 \mathrm{~h}$ at $40^{\circ} \mathrm{C}$ and aged for $6 \mathrm{~h}$ at $60^{\circ} \mathrm{C}$. The resulting sol was evaporated for $1 \mathrm{~h}$ to obtain a solid content of $80 \mathrm{w} / \mathrm{v} \%$.

\subsection{Composite Electrospinning}

For the electrospinning process, a solution of PVP in ethanol with concentration of $10 \mathrm{w} / \mathrm{v} \%$ was made. This solution was mixed with the silica sol at $10 \mathrm{w} / \mathrm{v} \%$ and calcium phosphate sol at 15 and $20 \mathrm{w} / \mathrm{v} \%$ for PVP weight. A hygroscopic white solid gel was obtained from the sol. The solutions were charged in syringes of $30 \mathrm{~mL}$ connected to a coaxial nozzle with double feeding. For the electrospinning process, a Nabond NEU-Pro device was used. The flow of the solutions was set in a range of 0.4 to $2.0 \mathrm{~mL} / \mathrm{h}$ in intervals of $0.2 \mathrm{~mL} / \mathrm{h}$. The voltage used was in a rage from 10 to $15 \mathrm{kV}$ and the distance between the nozzle and the collector in a range between 10 and $20 \mathrm{~cm}$ in intervals of $5 \mathrm{~cm}$. For the obtainment of the ceramic fibers, the green fibers were dried at $50^{\circ} \mathrm{C}$ for $24 \mathrm{~h}$ in a stove (Thermoscientific ${ }^{\circledR}$ mod. OSG60) and later heat treated in an muffle (Thermoscientific $\AA$ mod.FB1410M) at 800 and $900^{\circ} \mathrm{C}$ for $1 \mathrm{~h}$ with a temperature ramp of $0.5^{\circ} \mathrm{C} / \mathrm{min}$.

\section{Results and Discussions}

Figure 1a shows the fibers as spun with $\mathrm{SiO} 2-\mathrm{HA}$ flow of $1.2 \mathrm{~mL} / \mathrm{h}$, the fibers were cylindric, with homogeneous surface and random orientation. The average diameter of fibers was $560 \mathrm{~nm}$ $\pm 82 \mathrm{~nm}$. Figure $1 \mathrm{~b}$ shows fibers obtained with $\mathrm{SiO} 2$ flow of $8.0 \mathrm{~mL} / \mathrm{h}$ which were well shaped with an average diameter of $545 \mathrm{~nm} \pm 104 \mathrm{~nm}$. There were some regions in the membrane with accumulations of phosphate and a contrast zone throughout the inner part the fibers. A further reduction in the inner flow to $0.4 \mathrm{~mL} / \mathrm{h}$ to produce fibers with cylindric morphology and homogeneous surface and an average diameter of $510 \mathrm{~nm} \pm 90 \mathrm{~nm}$ is shown in Figure 1c. The same pattern of contrast is observed throughout the fibers (the contrast zone is segmented). All membranes obtained had HA particle agglomerations on the surface due to the instability of the jet during electrospinning causing the expulsion of droplets (Tian et al., 2015; Zhao et al., 2008). In the coaxial fibers manufactured with $\mathrm{SiO} 2$ flows of 0.8 and $0.4 \mathrm{~mL} / \mathrm{h}$ there were contrast areas 
arranged longitudinally of what is presumed to be $\mathrm{SiO} 2$ encapsulated in hydroxyapatite (Figure 1d).
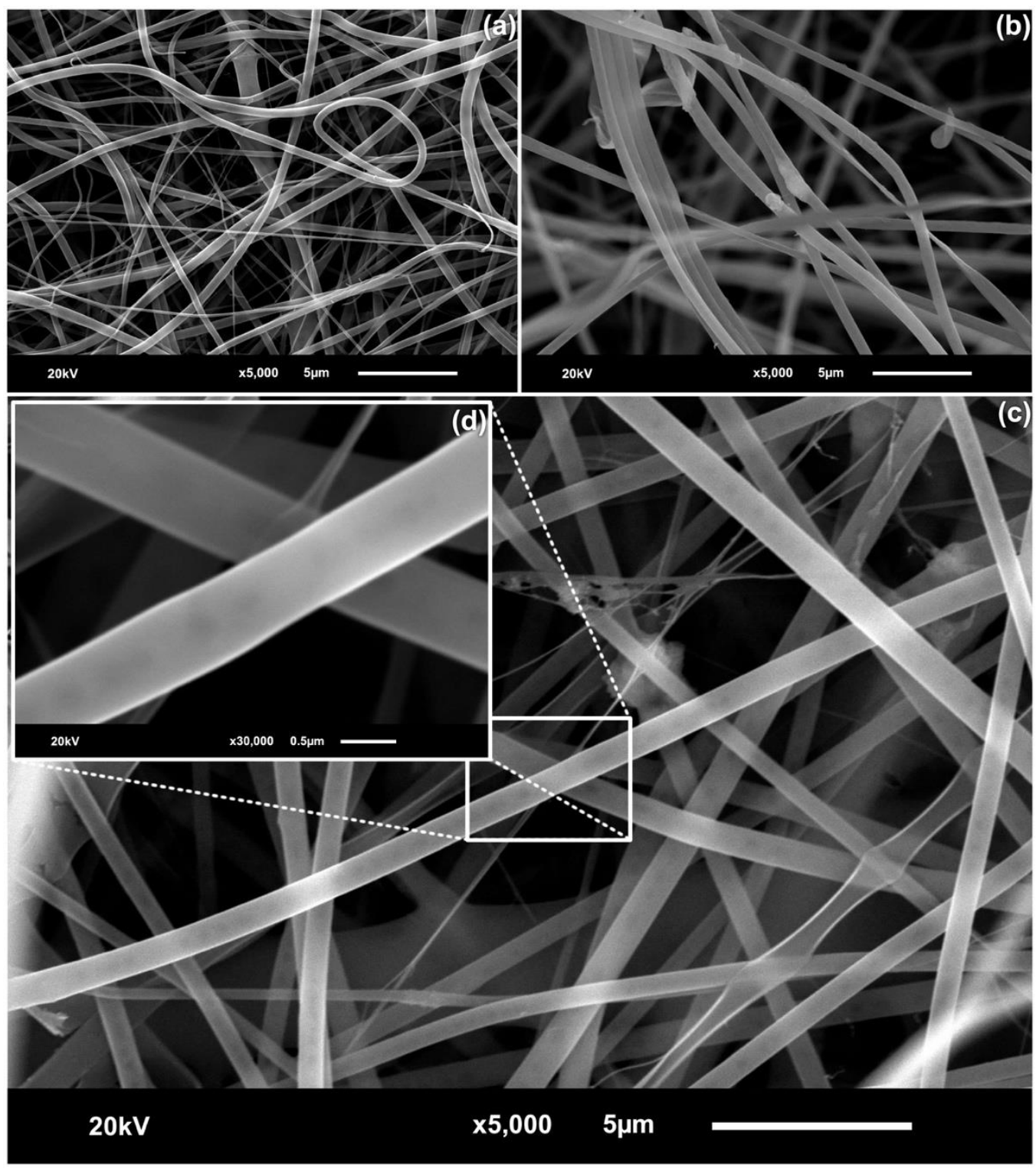

Figure 1: SEM micrograph of as-spun fibers of $\mathrm{SiO} 2-\mathrm{HA}$ at 5,000x with $\mathrm{SiO} 2$ flow of (a) 1.2 $\mathrm{mL} / \mathrm{h}$, (b) $0.8 \mathrm{~mL} / \mathrm{h}$ and (c) $0.4 \mathrm{~mL} / \mathrm{h}$ before the heat treatment. A contrast zone in the inner part of the fibers is shown in figure $1(\mathrm{~d})$.

TGA and DSC analysis were performed on the green fibers before the heat treatment. In Figure 2, thermogram shows an initial weight loss $(4 \%)$ around $90^{\circ} \mathrm{C}$ due to evaporation of ethanol and water. At $350^{\circ} \mathrm{C}$ there is a second weight loss of approximately $29 \%$ corresponding to the removal of residual and polymer. Around $440^{\circ} \mathrm{C}$ the weight of the sample was reduced by $62 \%$ due to the densification process in the ceramic material. Increasing the temperature beyond $600^{\circ} \mathrm{C}$ does not seem to produce any additional weight loss. Hence, the fiber at $600{ }^{\circ} \mathrm{C}$ is likely to produce a non-volatile residue containing predominantly hydroxyapatite and silica. In the 
DSC of the green fibers it can be seen an endothermic peak corresponding to the loss of solvents at $100^{\circ} \mathrm{C}$. An endothermic peak is located at $474^{\circ} \mathrm{C}$ due to the loss of organic material from the PVP and the metalorganic precursors. An exothermic peak is shown at $697^{\circ} \mathrm{C}$ because of the release of $\mathrm{CO} 2$ from the crystals of $\mathrm{CaCO} 3$ formed by the substitution of PO4-3 by (CO3-2) during the sol-gel synthesis. The material presents an endothermic peak around $1160^{\circ} \mathrm{C}$ corresponding to the final loss of $\mathrm{OH}$ - and densification of the ceramic network (Meejoo et al., 2006).

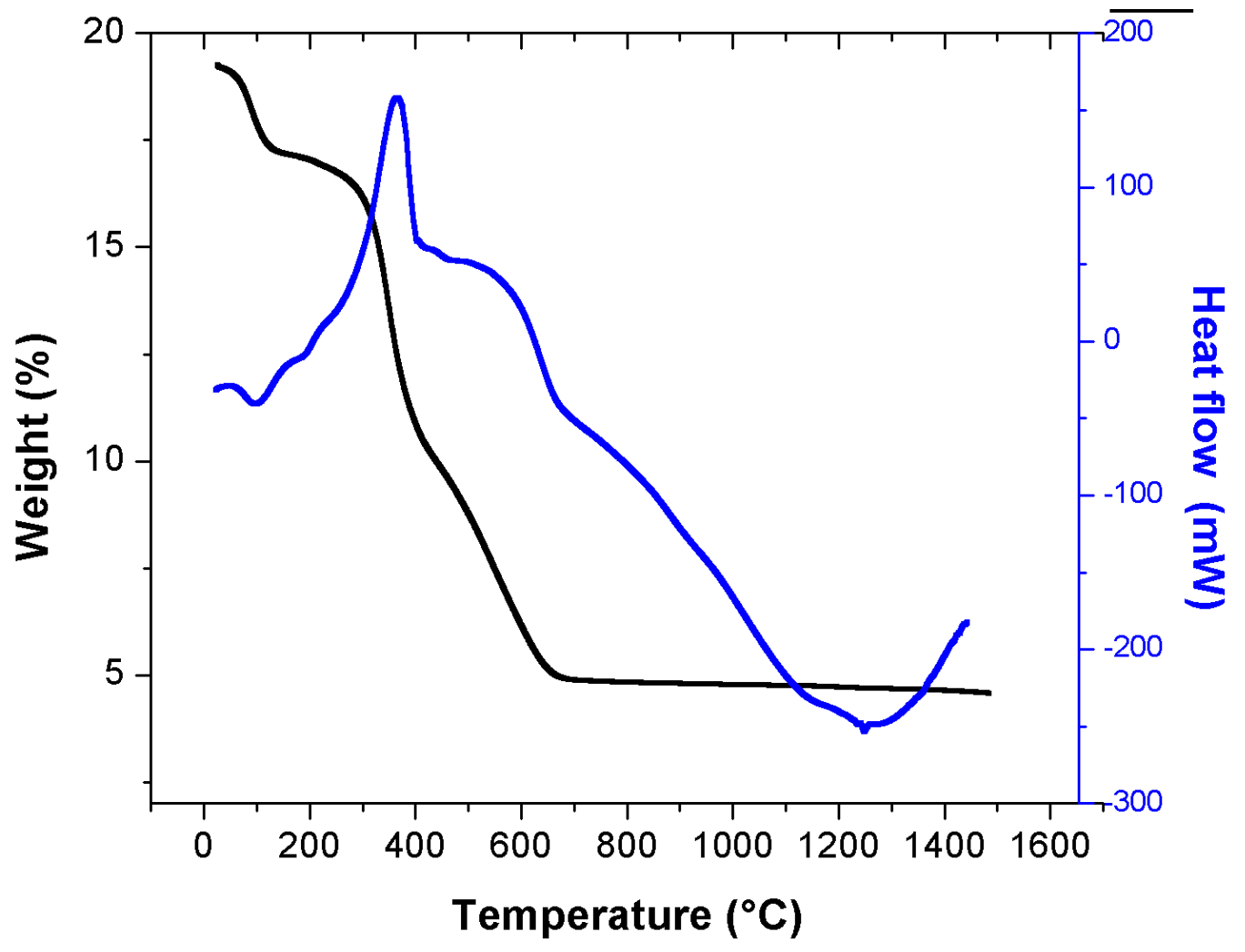

Figure 2: TGA-DSC of as-spun $\mathrm{SiO} 2-\mathrm{HA}$ fibers

The IR spectrum of the fibers before the heat treatment is shown in Figure 3 . At $25^{\circ} \mathrm{C}$ the spectra show absorption bands related to functional groups in the PVP, silica and the calcium phosphate (see Table I). Bands at 450, 560 and $960 \mathrm{~cm}-1$ correspond to vibrations of PO4-3 groups. A characteristic vibration of the $\mathrm{C}=\mathrm{O}$ group appears at $650 \mathrm{~cm}-1$ and at 1291 and $1424 \mathrm{~cm}-1$ belong to nitrogen of tertiary amine in PVP. At 1652 and $2955 \mathrm{~cm}-1$ bands correspond to bending vibrations of $\mathrm{H} 2 \mathrm{O}$ molecules and $\mathrm{C}-\mathrm{H}$ group in the polymer. At $800^{\circ} \mathrm{C}$ the IR spectrum changed and the bands corresponding to groups in the PVP disappeared (see Table II). At 450, 560 and $960 \mathrm{~cm}-1$ bands belonging to PO4-3 groups in HA appear. The bands at 800 and $1066 \mathrm{~cm}-1$ are related to deforming vibrations of $\mathrm{Si}-\mathrm{O}-\mathrm{Si}$ groups and at $1405 \mathrm{~cm}-1$ there is a slight bump in a band that corresponds to $\alpha$-TCP (tricalcium phosphate). 


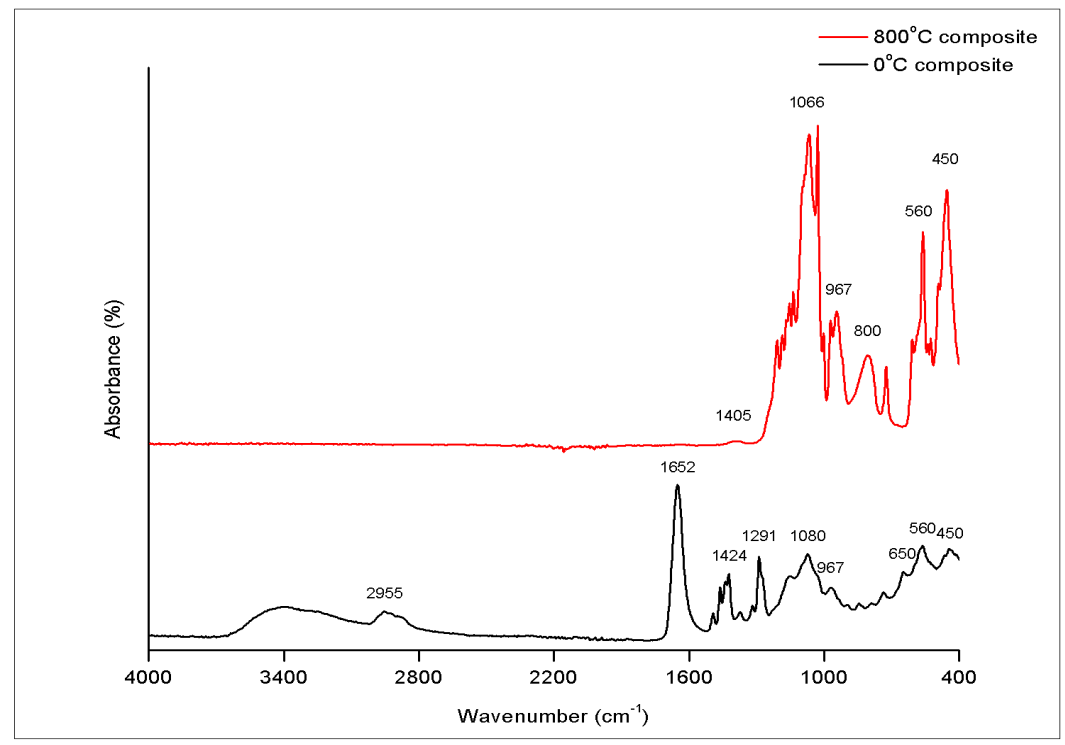

Figure 3: ATR-IR spectra of SiO2-HA fibers before and after heat treatment

Table 1: IR bands observed in $\mathrm{SiO}_{2}$-HA fibers at $25^{\circ} \mathrm{C}$

\begin{tabular}{ll}
\hline Wavenumber $\left(\mathbf{c m}^{-1}\right)$ & Vibration \\
\hline 450 & $\mathrm{PO}_{4}^{3-} v_{2}$ \\
560 & $\mathrm{PO}_{4}{ }^{3-} v_{4}$ \\
650 & $\mathrm{~N}-\mathrm{C}=\mathrm{O} v_{b}$ \\
960 & $\mathrm{PO}_{4}^{3-} v_{1}$ \\
1080 & $\mathrm{Si}-\mathrm{O}-\mathrm{Si}$ \\
1291 & $\mathrm{C}-\mathrm{N}$ \\
1424 & $\mathrm{C}-\mathrm{N} v_{b}$ \\
1652 & $\mathrm{H}-\mathrm{O} v_{s}$ \\
2955 & $\mathrm{C}-\mathrm{H} v_{a s}$ \\
\hline
\end{tabular}

Table 2: IR bands observed in $\mathrm{SiO}_{2}$-HA fibers at $800{ }^{\circ} \mathrm{C}$

\begin{tabular}{ll}
\hline Wavenumber $\left(\mathbf{c m}^{-1}\right)$ & Vibration \\
\hline 450 & $\mathrm{PO}_{4}{ }^{3-} v_{2}$ \\
560 & $\mathrm{PO}_{4}{ }^{3-} v_{4}$ \\
800 & $\mathrm{Si}-\mathrm{O}-\mathrm{Si} v_{a s}$ \\
960 & $\mathrm{PO}_{4}{ }^{3-} v_{1}$ \\
1066 & $\mathrm{Si}-\mathrm{O}-\mathrm{Si} v_{b}$ \\
1405 & $\alpha-\mathrm{TCP}$ \\
\hline
\end{tabular}


After the heat treatment, the fiber diameter was reduced and in all the membranes. The fibers exhibited spindle-thread morphology and they were interconnected as seen in Figure 4, which shows fibers prepared with $\mathrm{SiO} 2$ flow of $1.8 \mathrm{~mL} / \mathrm{h}$ (a), $0.8 \mathrm{~mL} / \mathrm{h} \mathrm{(b)} \mathrm{and} 0.4 \mathrm{~mL} / \mathrm{h}$ (c). The average diameter of the fibers in each membrane was $330 \mathrm{~nm} \pm 85 \mathrm{~nm}, 320 \mathrm{~nm} \pm 95 \mathrm{~nm}$ and de $300 \mathrm{~nm} \pm 85 \mathrm{~nm}$ respectively. There were zones in the membranes with accumulation of HA, specifically in Figure $4 \mathrm{c}$ and $4 \mathrm{~d}$. The membranes were dense, and the fibers had an overall smooth surface. The morphology of the fibers after the heat treatment shows patterns of thread and spindle, or throttling of the fiber which is attributed to the presence of $\mathrm{SiO} 2$ on the inside the hydroxyapatite cover which prevents the contraction thereof during sintering (Tian et al, 2015; Sun et al., 2006).

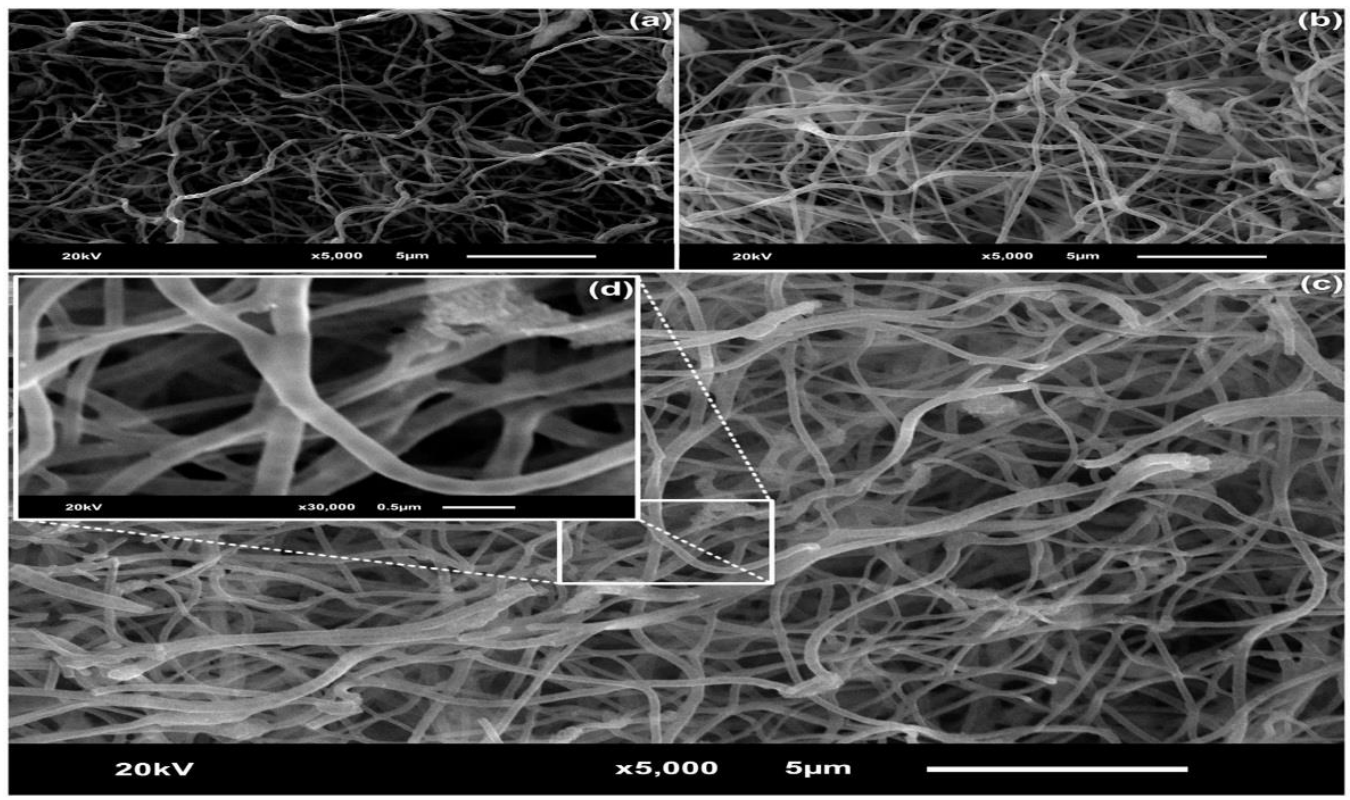

Figure 4: SEM micrograph of fibers of $\mathrm{SiO} 2-\mathrm{HA}$ at $5,000 \mathrm{x}$ after $800^{\circ} \mathrm{C}$ heat treatment and $\mathrm{SiO} 2$ flow of (a) $1.2 \mathrm{~mL} / \mathrm{h}$, (b) $0.8 \mathrm{~mL} / \mathrm{h}$ and (c) $0.4 \mathrm{~mL} / \mathrm{h}$ before the heat treatment. Constriction along the fibers is shown in figure $4(\mathrm{~d})$.

The analysis of the fibers by XRD shows in Figure 5 defined peaks associated to the planes of hydroxyapatite (002), (211), (310) (300) and (202) among others, corresponding to the file card [JCPDS file \#09-0432], while most of the pattern may be due for amorphous glass phase per the infrared spectra of $\mathrm{SiO} 2-\mathrm{HA}$. It is observed that the crystal size increases with increasing calcination temperature. The indexed peaks are consistent with the data of Liu et al. in 2001, who studied line-breadth of the (002) peak at $2 \theta=25.83 \mathrm{o}$ of apatite gels calcined at different temperatures. 


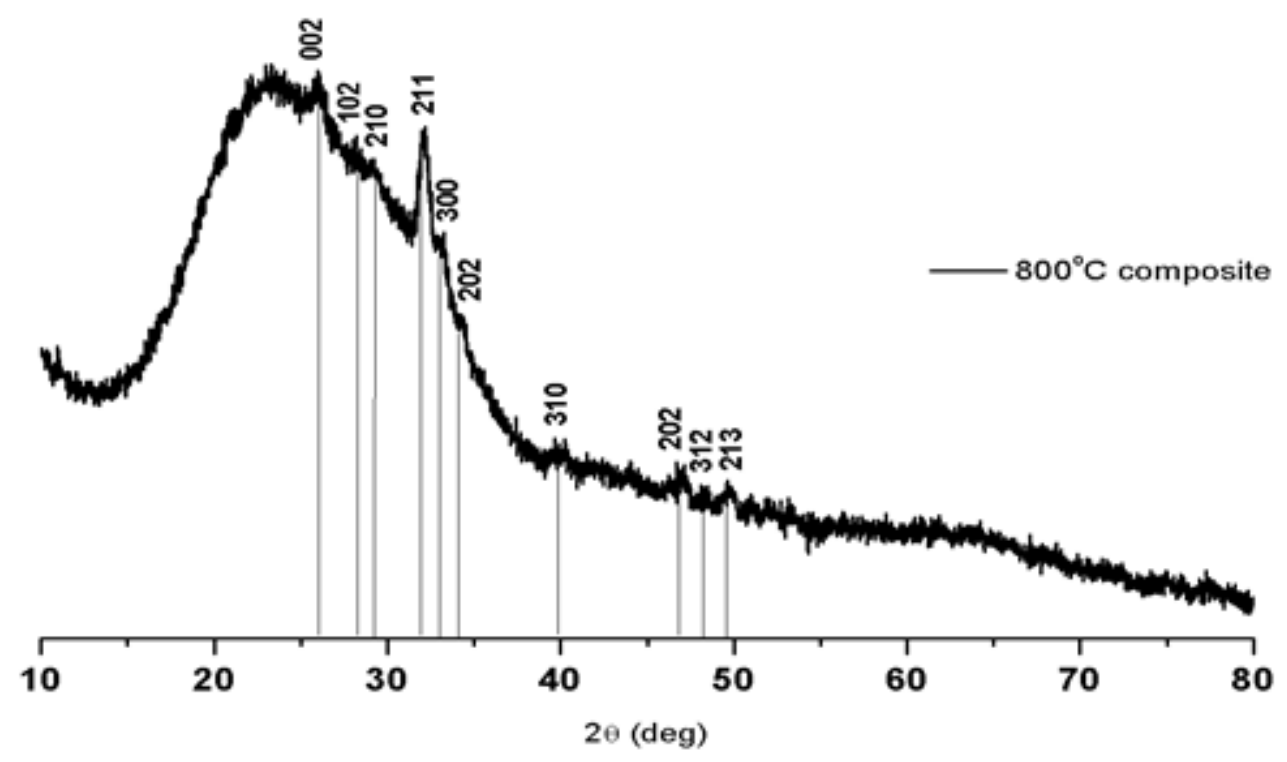

Figure 5: XRD pattern of SiO2-HA composite fibers after heat treatment

Hydroxyapatite particles, fibers and coatings prepared by various techniques have been used extensively in many biomedical applications. The sol-gel process combined with electrospinning has been demonstrated as a suitable method to produce hydroxyapatite-SiO2 fibers with diameters on the order of $0.3 \mu \mathrm{m}$. The membrane structures would be highly desirable as bone substitutes or tissue engineering templates. The material aspects of electrospun nanofibers such as fabrication, properties and functioning have already been explored in detail and suggested positive outcome for intended biomedical applications. The progress of electrospun materials for various oral applications is promising; however, there is lack of in vivo and clinical studies (Zafar et al., 2016).

\section{Conclusions \& Recommendations}

Glass-Hydroxyapatite fibrous networks with average fiber diameters between $300 \mathrm{~nm}$ to $400 \mathrm{~nm}$ were produced after calcination of electrospun PVP/HA/TEOS/sol mixtures. X-ray diffraction and infrared analysis indicated hydroxyapatite and silica to be the dominant inorganic phases remaining after firing. A continuous fibrous network could be obtained with a uniform dispersion of hydroxyapatite. For dental tissue engineering the present Glass-Hydroxyapatite fibrous network is a suitable microenvironment for dental regeneration, while it is expected that the combination of the two ceramics in a nanofiber membrane improved the mechanical properties and functionalities for biological aspects in dental applications.

\section{Acknowledgements}

Authors gratefully acknowledge financial support by CONACYT and PROMEP. S. Reyes-Lopez thanks Dr. Carlos Rodriguez for SEM images. 


\section{References}

[1] Basu B, Balani K. Advanced Structural Ceramics. New Jersey: John Wiley \& Sons, Inc., 2011:393-421, 67-75.

[2] Bocaccini A. Ceramics. In: Hench LL, Jones J, eds. Biomaterials, artificial organs and tissue engineering. Cambridge: Woodhead Publishing Limited, 2005:26-36.

[3] Dinarvand P, Seyedjafari E, Shafiee A, Jandaghi AB, Doostmohammadi A, Fathi MH, Farhadian S, Soleimani M. New Approach to Bone Tissue Engineering: Simultaneous Application of Hydroxyapatite and Bioactive Glass Coated on a Poly (L-lactic acid) Scaffold. ACS Appl Mater Interfaces $2011 ; 3: 4518-4524$.

[4] Hench LL, Kokubo T. Properties of bioactive glasses and glass-ceramics. In: Black J, Hastings G, eds. Handbook of Biomaterial Properties. London: Chapman \& Hall, 1998:355-405.

[5] Lee J, Kim Y. Hydroxyapatite nanofibers fabricated through electrospinning and sol-gel process. Ceram Int 2014; 40:3361-3369.

[6] Leeuwenburgh SCG, Wolke JGC, Jansen JA; De Groot K. Calcium phosphates coatings. In: Kokubo T, ed. Bioceramics and their clinical applications. Cambridge: Woodhead Publishing Limited, 2008:464-484.

[7] Liu D, Troczynski T, Tseng WJ. Water-based sol-gel synthesis of hydroxyapatite: process development. Biomaterials 2001; 22:1721-1730.

[8] López-Esparza J, Espinosa-Cristóbal LF, Donohue-Cornejo A, Reyes-López SY. (2016). Antimicrobial Activity of Silver Nanoparticles in Polycaprolactone Nanofibers against GramPositive and Gram-Negative Bacteria. Ind Eng Chem Res 2016;55(49):12532-12538.

[9] Meejoo S, Maneeprakorn W, Winotai P. Phase and thermal stability of nanocrystalline hydroxyapatite prepared via microwave heating. Thermochim Acta 2006; 447:115-120.

[10] Reyes-López SY, Cornejo-Monroy D, González-García G. A novel route for the preparation of Gold nanoparticles in Polycaprolactone nanofibers. J Nanomater 2015; 16(1):153.

[11] Roque-Ruiz J., Cabrera-Ontiveros E., Torres-Pérez J. and Reyes-López S., Preparation of PCL/Clay and PVA/Clay Electrospun Fibers for Cadmium $(\mathrm{Cd}+2)$, Chromium $(\mathrm{Cr}+3)$, Copper $(\mathrm{Cu}+2)$ and Lead $(\mathrm{Pb}+2)$ Removal from Water, Water, Air, \& Soil Pollution, 2016, 227,8,1-17.

[12] Roveri N, Falini G, Sidoti MC, Tampieri A, Landi E, Sandri M, Parma B. Biologically inspired growth of hydroxyapatite nanocrystals inside self-assembled collagen fibers. Mater Sci Eng C 2003; 23:441-446.

[13] Tian M, Gao Y, Liu Y, Liao Y, Xu R, Hedin NE, Fong H. Bis-GMA/TEGDMA dental composites reinforced with electrospun nylon 6 nanocomposite nanofibers containing highly aligned fibrillar silicate single crystals. Polymer 2007; 48:2720-2728.

[14] Tian L, Zi-qiang S, Jian-quan W, Mu-jia G. Fabrication of hydroxyapatite nanoparticles decorated cellulose triacetate nanofibers for protein adsorption by coaxial electrospinning. Chem Eng J 2015; 260:818-825.

[15] Sun B, Duan B, Yuan X. Preparation of Core/Shell PVP/PLA Ultrafine Fibers by Coaxial Electrospinning. J Appl Polym Sci 2006; 102:39-45.

[16] Zafar M, Najeeb S, Khurshid Z, Vazirzadeh M, Zohaib S, Najeeb B, Sefat F. Potential of electrospun nanofibers for biomedical and dental applications. Materials 2016; 9:73.

[17] Zhao Y, Wang H, Lu X, Li X, Yang Y, Wang C. Fabrication of refining mesoporous silica nanofibers via electrospinning. Mater Lett 2008; 62:143-146.

*Corresponding author.

E-mail address: simon.reyes@uacj.mx 